\title{
Mewujudkan Desa Wisata melalui Pembekalan Clean, Health, Safety \& Environment, Pelayanan Prima dan Exploring, Packaging \& Presentation
}

\section{Realizing a Tourism Village through Provision of Clean, Health, Safety \& Environment, Excellent Service and Exploring, Packaging \& Presentation}

\author{
Sintia Safrianti ${ }^{*}$, Risnita Tri Utami ${ }^{2}$, Dedi Pardiansyah ${ }^{2}$, Yulfiperius ${ }^{2}$ \\ ${ }^{1}$ Program Studi Manajemen Universitas Prof. Dr. Hazairin SH, Jl. Jend. A. Yani No. 1 Bengkulu, Indonesia \\ ${ }^{2}$ Program Studi Akuakultur Universitas Prof. Dr. Hazairin SH, Jl. Jend. Sudirman No. 185 Bengkulu, Indonesia
}

\begin{tabular}{l}
\hline Info Artikel \\
\hline Diterima 27 Februari 2021 \\
Ditelaah 17 Juni 2021 \\
Disetujui 23 Juni 2021 \\
Tersedia daring 30 Juni 2021 \\
*Penulis untuk korespondensi \\
sintiasafrianti19@gmail.com \\
\hline \\
Kata Kunci: \\
CHSE, \\
EPP, \\
Pelayanan Prima, \\
Pendampingan Desa Wisata, \\
Bimbingan Teknis \\
\hline
\end{tabular}

Keywords:

CHSE,

Excellent Service,

EPP,

Village Tourism Assistance,

Technical Guidance

\begin{abstract}
ABSTRAK
Desa Sumber Urip, Kecamatan Selupu Rejang, Kabupaten Rejang Lebong merupakan salah satu desa wisata di Provinsi Bengkulu yang membutuhkan pengembangan wisata. Kementerian Pariwisata dan Ekonomi Kreatif Republik Indonesia bersama Universitas Prof. Dr. Hazairin, SH Bengkulu mengadakan pendampingan pengembangan Desa Wisata Regional 1 A (Sumatera) dengan tujuan memberikan pemahanan kepada peserta mengenai pentingnya menerapkan clean, health, safety \& environment, pelayanan prima dan exploring, packaging \& presentation dalam membangun desa wisata. Tujuan lainnya adalah untuk meningkatkan gerakan sadar wisata sehingga dapat mengembangkan potensi kebudayaan dan wisata yang terdapat di desa wisata. Kegiatan dilaksanakan pada tanggal 8 September 2020 dan dilanjutkan dengan pendampingan di Desa Sumber Urip. Bimbingan teknis diikuti oleh 25 perserta dari kelompok masyarakat sadar wisata, badan usaha milik desa, perangkat desa dan para pendamping yang berasal dari mahasiswa. Secara keseluruhan, kegiatan berlangsung dengan sukses dan mendapat respon yang positif dari para peserta. Sebanyak $100 \%$ peserta menyatakan kepuasan terhadap materi tentang pengembangan desa wisata yang disajikan dalam kegiatan pengabdian pada masyarakat ini.
\end{abstract} ABSTRACT
Sumber Urip Village, Selupu Rejang District, Rejang Lebong Regency is one of the
tourist villages in Bengkulu Province that requires tourism development. The Ministry
of Tourism and Creative Economy of the Republic of Indonesia in collaboration with
Universitas Prof. Dr. Hazairin, SH Bengkulu held the development of Regional Tourism
Village 1 A (Sumatra) with the aim of providing understanding to participants about the
importance of implementing clean, health, safety \& environment, excellent service and
explore, packaging \& presentation in building a tourist village. Another goal was to
increase the tourism awareness movement so that it could develop the cultural and
tourism potential that exists in tourist villages. The activity was carried out on September
8,2020 and continued with assistance in Sumber Urip Village. The technical guidance
was attended by 25 participants from tourism-aware community groups, village-owned
enterprises, village officials and assistants from students. Overall, the activity was
successful and received a positive response from the participants. 100\% of participants
expressed satisfaction with the material about the development of tourist villages
presented in this community service activity. ISSN 2685-0354 (Media Online). Diterbitkan oleh Universitas Prof. Dr. Hazairin, SH. Ini merupakan jur
bawah lisensi Creative Commons Atribution 4.0 International (https://creativecommons.org/licenses/by/4.0

\section{PENDAHULUAN}

Selama beberapa dekade, pariwisata menjadi salah satu sektor ekonomi dunia yang paling cepat berkembang (Brunner, 2010). Begitu pun di Indonesia, perkembanga pariwisata sangat pesat. Perkembangan pariwisata Indonesia yang sangat besar dan beragam dapat dikembangkan menjadi destinasi wisata yang menarik dan utama untuk wisata 
dunia (Hakim et al., 2019). Kegiatan pembangunan pariwisata melibatkan peran dari seluruh pemangku kepentingan yang ada dan terkait (pentahelix), yaitu: pemerintah, pelaku usaha/industri pariwisata, masyarakat, institusi pendidikan dan media dengan peran dan fungsinya masing-masing (Yadisaputra \& Palupi, 2018).

Desa wisata didefinisikan sebagai kawasan pedesaan yang dipergunakan untuk tujuan wisata dengan menyajikan alam dan budaya masyarakatnya sebagai daya tarik (Andayani et al., 2017). Desa wisata juga merupakan wadah pemberdayaan masyarakat dalam mengembangkan desanya. Melalui pengembangan desa wisata, diharapkan terjadi pemerataan yang sesuai dengan konsep pembangunan pariwisata yang berkesinambungan (Gautama et al., 2020). Pembangunan dan pengembangan desa wisata akan sejalan dengan keberlangsunan alam, sosial dan budaya yang memanfaatkan sumberdaya lokal, pencapaian kesejahteraan, dan peningkatan taraf hidup masyarakat (Rusyidi \& Fedryansah, 2018). Suatu kawasan dikatakan dapat menjadi desa wisata harus memperhatikan factor kelangkaan, kealamiahan, keunikan dan pemberdayaan masyarakat (Kurniawan \& Prakoso, 2008). Daya tarik suatu desa wisata merupakan faktor yang menentukan kepuasan wisatawan (Hermawan, 2017).

Sasaran utama pengembangan kepariwisataan haruslah meningkatkan kesejahteraan masyarakat setempat (Ritchi et al., 2018). Dukungan masyarakat melalui peran dan fungsinya dalam kegiatan pariwisata merupakan salah satu tujuan dari pengembangan kepariwisataan karena kepariwisataan harus pro job (menciptakan lapangan kerja), pro poor (menanggulangi dan mengurangi kemiskinan), pro growth (mendorong pertumbuhan), dan pro environment (memperhatikan lingkungan). Pengelolaan desa wisata diharapkan akan berkembang dengan baik, salah satunya melalui perencanaan berbasis masyarakat (Gautama et al., 2020). Untuk mewujudkan desa wisata yang baik masyarakat harus memiliki sikap sadar wisata. Sadar Wisata adalah suatu kondisi yang menggambarkan partisipasi dan dukungan segenap komponen masyarakat dalam mendorong terwujudnya iklim yang kondusif bagi tumbuh dan berkembangnya kepariwisataan di suatu destinasi atau wilayah (Rahim, 2012). Tujuan dari Gerakan Sadar Wisata adalah menumbuhkan kesadaran dan peran seluruh komponen masyarakat dalam perannya sebagai tuan rumah untuk menerapkan dan mewujudkan Sapta Pesona; menggerakkan dan menumbuhkan motivasi, kemampuan dan kesempatan bagi masyarakat sebagai wisatawan. Sapta Pesona merupakan jabaran konsep sadar wisata yang terkait dengan dukungan dan peran masyarakat sebagai tuan rumah dalam upaya untuk menciptakan lingkungan dan suasana kondusif yang mampu mendorong dan tumbuh berkembangnya industri pariwisata, melalui perwujudan unsur Aman, Tertib, Bersih, Sejuk, Indah, Ramah, dan Kenangan (Kementerian Pariwisata \& Ekonomi Kreatif, 2012).

Unsur-unsur Sapta Pesona tersebut telah menjadi bagian yang tak terpisahkan dalam program-program pembangunan kepariwisataan yang dilaksanakan selama dua dekade yang lalu, seiring dengan upaya pemantapan posisi sektor pariwisata sebagai sektor andalan dalam perolehan devisa negara, maupun sebagai instrumen pembangunan yang strategis di daerah, baik dalam konteks pengembangan wilayah dan peningkatan kesejahteraan rakyat (Peraturan Menteri Kebudayaan dan Pariwisata Nomor PM.04/UM.001/MKP/2008). Exploring adalah menjelajah atau mengidetifikasi produk pariwisata, yang perlu dilakukan terlebih dahulu kenali kualitas produk. Dimensi kualitas produk yang terdiri dari dimensi core product, actual product dan augmented product adalah salah satu dimensi kualitas produk yang perlu dikembangakan secara terus menerus dan berkesinambungan (Kotler \& Amstrong, 2001). Packaging (kemasan) adalah desain kreatif yang menghubungkan bentuk, struktur, material, warna, citra, tipografi dan elemen-elemen desain dengan informasi produk agar produk dapat di pasarkan (Klimchuk \& Krasovec, 2006). Pengemasan adalah kegiatan merancang dan memproduksi wadah atau bungkus sebagai sebuah produk (Kotler \& Keller, 2009).

Dalam pemikiran modern mengenai pemberdayaan, masyarakat tidak lagi diposisikan sebagai objek melainkan sebagai subjek. Masyarakat sebagai subjek dipandang sebagai komunitas yang memiliki potensi sesuai dengan kultur yang berkembang pada masyarakat tersebut (Pratama, 2019). Untuk mewujudkan masyarakat sebagai subjek, masyarakat memerlukan bimbingan khusus. Di tengah semangat memasuki era new normal ini, Kementerian Pariwisata dan Ekonomi Kreatif Republik Indonesia (Kemenparekraf RI) kembali memfasilitasi akademisi dalam pengabdian kepada masyarakat melalui program pemberdayaan masyarakat di desa wisata (Fitriana et al., 2020). Berdasarkan hal tersebut Kementerian Pariwisata dan Ekonomi Kreatif (Kemenparekraf) Republik Indonesia bersama Universitas Prof. Dr. Hazairin, SH Bengkulu mengadakan Bimbingan Teknis Pendampingan Desa Wisata Regional 1 A (Sumatera) Tahun 2020 dengan peserta yang merupakan masyarakat Desa Sumber Urip. Desa Sumber Urip terletak di Kecamatan Selupu Rejang, Kabupaten Rejang Lebong. Desa Sumber Urip merupakan salah satu desa wisata di Provinsi Bengkulu. Oleh karena itu, Desa Sumber Urip membutuhkan pendampingan untuk menunjang pengembangan desa wisata khususnya. 


\title{
METODE
}

Peserta kegiatan merupakan setiap peran yang terlibat dalam pengembangan desa wisata Sumber Urip (Gambar 1). Desa ini memiliki luas wilayah hanya $650 \mathrm{~km}^{2}$. Wisata yang termasuk ke dalam Desa Wisata Sumber Urip adalah Taman Wisata Bukit Kaba atau Gunung Kaba, wisata pemandian air panas Gerojokan Sewu yang berjarak sekitar 1 $\mathrm{km}$ dari jalan utama dan berada di kaki Gunung Api Bukit Kaba dan wisata panen madu. Wisata desa ini didukung oleh pemandangan yang masih asri serta perkebunan sayur milik warga.

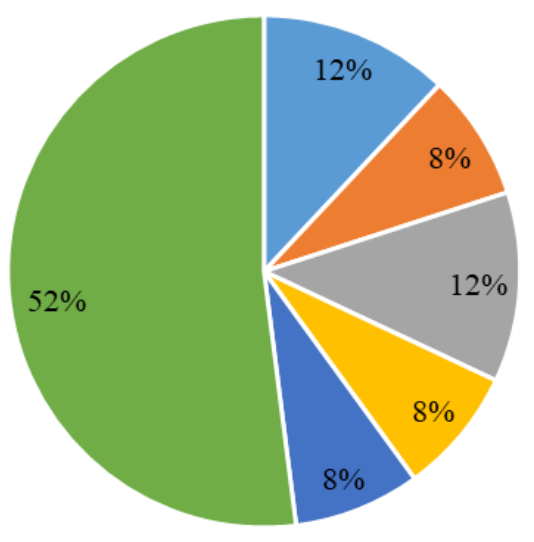

\author{
- Perangkat Desa \\ - Badan Usaha Milik Desa \\ - Kelompok Sadar Wisata \\ " Pengusaha Home Stay \\ - Pengusaha lebah madu \\ - Mahasiswa calon \\ pendamping desa wisata
}

Gambar 1 Peserta kegiatan dari berbagai peran dalam desa wisata

Kegiatan Bimbingan Teknis Pendampingan Desa Wisata Regional 1 A (Sumatera) dilaksanakan di Hotel Mercure Bengkulu pada tanggal 8 September 2020 dan diikuti oleh 25 orang. Metode yang digunakan dalam kegiatan ini adalah:

1. Metode ceramah: Narasumber memberikan materi mengenai CHSE (Clean, Healt, Safety dan Environment), Pelayanan Prima dan Exploring, Packaging \& Presentation dalam bentuk presentasi yang sifatnya teoritis.

2. Metode diskusi dan tanya jawab: Metode diskusi dan tanya jawab dilakukan untuk menambah pemahaman para peserta terkait materi yang telah disampaikan oleh para narasumber.

3. Metode evaluasi: Metode evaluasi merupakan tahapan akhir yang dilakukan untuk mengukur sampai dimana pemahaman peserta bimtek terkait materi yang telah disampaikan oleh para narasumber. Metode evaluasi dilakukan dengan menggunakan kuesioner yang diberikan kepada semua peserta kegiatan.

\section{HASIL DAN PEMBAHASAN}

Kegiatan Bimbingan Teknis Pendampingan Desa Wisata Regional 1A (Sumatera) dilaksanakan dilaksanakan terhadap masyarakat yang berperan dalam pengembangan desa wisata. Materi yang diberikan diantaranya adalah Sadar wisata dan Sapta Pesona; Clean, Health, Safety dan Environmetal Sustainability (CHSE); dan Pelayanan Prima, serta Exploring, Packaging dan Presentation yang disampaikan langsung oleh para narasumber (Tabel 1). Materi ini sejalan dengan program utama Kemenparekraf dalam pengembangan pariwisata di Indonesia yang berbasis CHSE.

Tabel 1. Topik Materi dan Narasumber Bimbingan Teknis Pendampingan Desa Wisata Regional 1A (Sumatera)

\begin{tabular}{cll}
\hline No. & \multicolumn{1}{c}{ Materi } & \multicolumn{1}{c}{ Narasumber } \\
\hline 1 & Sambutan dan kebijakan pariwisata di Indonesia & Kemenparekraf RI (Desti Muniariti, SE., MM) \\
2 & Sambutan dan kebijakan pariwisata di Provinsi Bengkulu & $\begin{array}{l}\text { Kepala Dinas Pariwisata Provinsi Bengkulu } \\
\text { (Irsan Setiawan SH, MM) }\end{array}$ \\
& & Dr. Ir. Yulfiperius, M.Si. \\
3 & Sadar wisata new normal & Dwi Oktavallyan S, S.T., M.Sc \\
4 & CSHE, Sapta Pesona, Pelayanan prima & 1. Dedi Pardiansyah, S.Pi., M.Si. \\
5 & $\begin{array}{l}\text { Pengembangan potensi produk wisata: } \\
\text { packaging, dan presentation }\end{array}$ & 2. Risnita Tri Utami, S. Kel., M. Si. \\
& & 3. Sintia Safrianti, S.E. M.M \\
\hline
\end{tabular}


Bimbingan teknis diawali dengan pemberian sambutan dan pemaparan kebijakan kepariwisataan nasional oleh Kemenparekraf dan dilanjutkan sambutan, pemaparan kebijakan kepariwisataan daerah Bengkulu sekaligus pembukaan bimbingan teknis oleh Kepala Dinas Pariwisata Provinsi Bengkulu (Gambar 2). Setelah acara pembukaan, langsung dilanjutkan dengan pemberian materi oleh para narasumber. Penyampaian materi diberikan waktu 45 menit pada masing-masing narasumber dan dilanjutkan dengan diskusi dan tanya jawab pada masing-masing narasumber.

Peserta mendapatkan pemaparan materi mengenai sadar wisata dan sapta pesona. Pada pemaparan tentang sadar wisata dan sapta pesona, narasumber membahas lebih dengan rinci mengenai pengertian dari sadar wisata, konsep sapta pesona dan contoh mengenai penerapan sadar wisata melalui sapta pesona. Dari pemaparan materi tersebut, peserta bimtek menjadi lebih yakin bahwa pentingnya sadar wisata dalam mendukung pengembangan pariwisata, partisipasi dan dukungan masyarakat sangat berpengaruh untuk mendirikan desa wisata dari yang merintis sampai menuju ke kategori yang lebih baik (Gambar 3).

CHSE dan Pelayanan Prima yang disampaikan oleh narasumber membahas mengenai penerapan CHSE di destinasi wisata, merancang panduan CHSE disesuaikan dengan kondisi di Desa Sumber Urip, mendorong keberlanjutan penerapan CHSE di desa wisata, pentingnya pelayanan prima dalam pengelolaan desa wisata dan penerapan sikap pelayanan yang dapat memuaskan wisatawan/pelanggan. Dalam materi ini peserta memahami pentingnya penerapan CHSE apalagi dalam kondisi saat pandemi virus Covid-19. Clean, Healthy, Safety dan Environment adalah pelajaran penting untuk masyarakat desa wisata untuk mendorong upaya pemulihan, kesiapan destinasi dan rebound strategi dalam rangka tatanan keabnormalan baru serta membangun kepercayaan publik, meningkatkan minat/preferensi wisatawan dan menciptakan destination appeal melalui penerapan program CHSE serta pelayanan prima ditujukan untuk masyarakat desa betapa pentingnya pelayanan dalam pengelolaan desa wisata (Gambar 3).

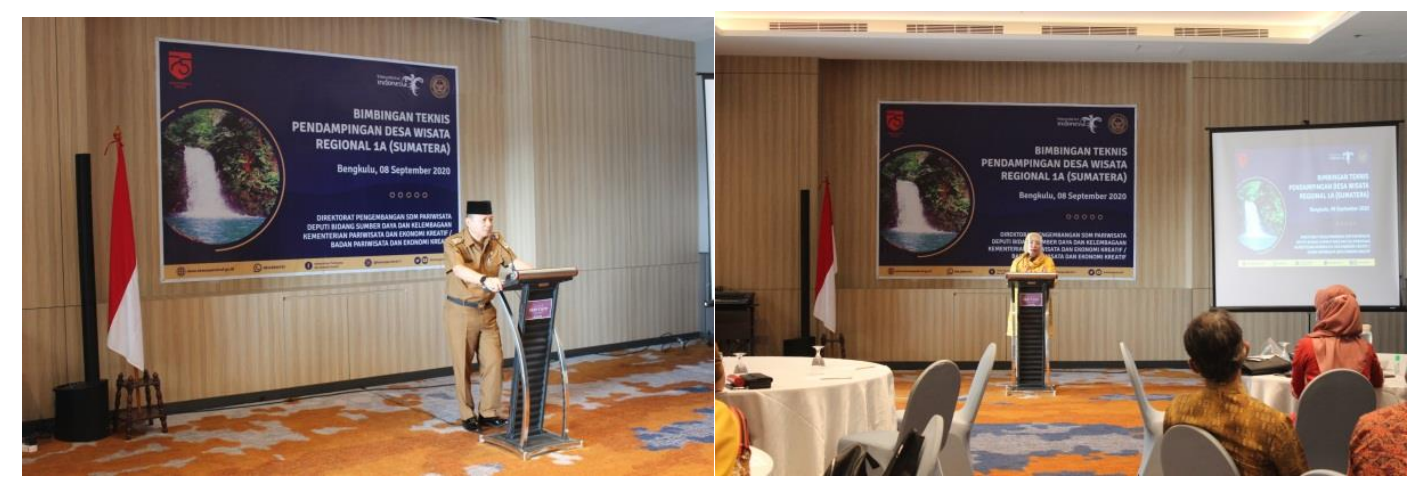

Gambar 2 Penyampaian arahan dan kebijakan kepariwisataan nasional dan daerah Bengkulu

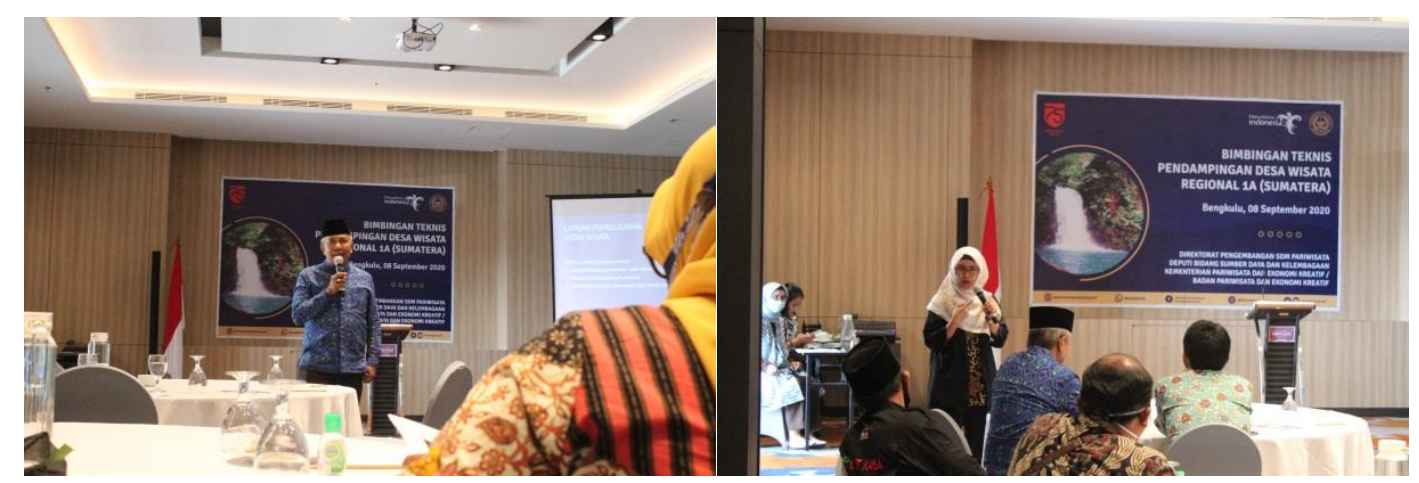

Gambar 3 Penyampaian materi mengenai sadar wisata \& sapta pesona dan CHSE \& pelayanan prima

Materi Exploring, Packaging dan Presentation disampaikan meliputi pemahaman dan membentuk karakter pribadi dan produk yang unggul di Desa Wisata (Gambar 4). Ini mencakup cara meningkatkan kompetensi pengelola Desa Wisata agar memiliki pemikiran terbuka dalam pengembangan Produk/Paket Wisata dan mampu mengeksplor potensi produk pariwisata unggulan melalui packaging. Pengembangan daerah wisata dengan knsep demikian akan menjadi daya tarik wisata bagi para wisatawan. Peserta dilatihkan menentukan segmentasi pasar sesuai dengan 
kapasitas Desa Wisata. Pada pemaparan materi packaging misalnya ditampilkan langsung contoh paket packaging madu Desa Sumber Urip dari yang tidak beridentitas kemudian diubah menjadi packaging yang berkesan dengan menggunakan label dan wadah yang lebih berkualitas. Contoh packaging lain yang ditampilkan contoh mengenai packaging tanaman sayuran yang lebih menarik untuk menambah nilai produk, selain dari packaging produk.

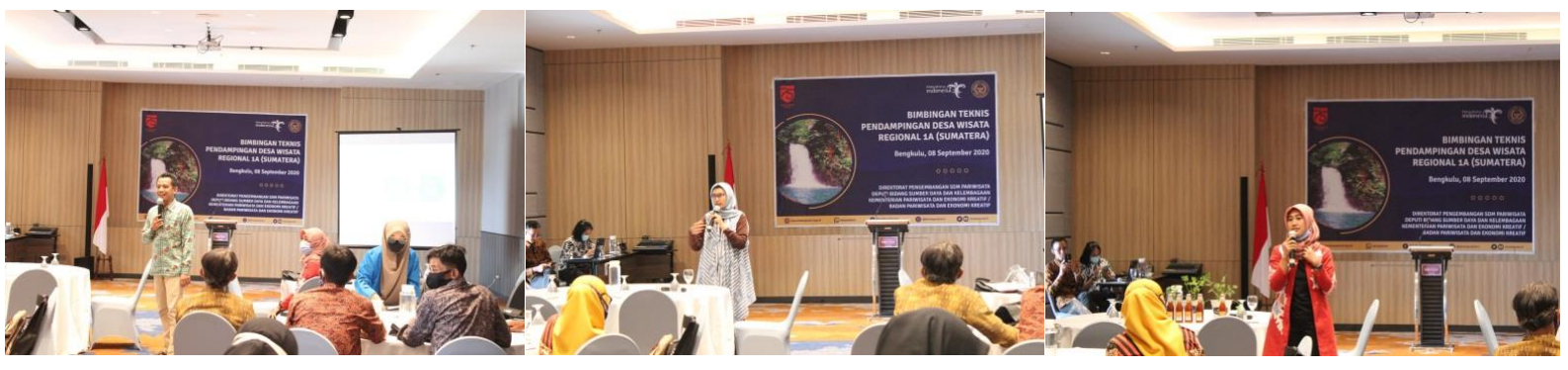

Gambar 4 Penyampaian materi mengenai Exploring, Packaging dan Presentation

Tabel 2. Indikator capaian pelaksanaan kegiatan pengabdian pada masyarakat

\begin{tabular}{|c|c|c|c|c|c|c|}
\hline \multirow[b]{2}{*}{ No. } & \multirow[b]{2}{*}{ Penyelenggaraan Pelatihan } & \multicolumn{5}{|c|}{ Skor } \\
\hline & & $\begin{array}{l}\text { Sangat } \\
\text { tidak baik }\end{array}$ & Tidak baik & Cukup & Baik & Sangat baik \\
\hline 1 & Tema pelatihan & $0 \%$ & $0 \%$ & $8 \%$ & $36 \%$ & $56 \%$ \\
\hline 2 & Ketepatan waktu suasana & $0 \%$ & $0 \%$ & $4 \%$ & $44 \%$ & $52 \%$ \\
\hline 3 & Kelengkapan materi & $0 \%$ & $0 \%$ & $8 \%$ & $34 \%$ & $58 \%$ \\
\hline 4 & Sikap penyelenggara & $0 \%$ & $0 \%$ & $4 \%$ & $28 \%$ & $68 \%$ \\
\hline \multirow[t]{2}{*}{5} & Alat bantu & $0 \%$ & $0 \%$ & $8 \%$ & $38 \%$ & $54 \%$ \\
\hline & Narasumber & & & & & \\
\hline 1 & Penguasaan materi & $0 \%$ & $0 \%$ & $12 \%$ & $52 \%$ & $36 \%$ \\
\hline 2 & Metode yang digunakan & $0 \%$ & $0 \%$ & $16 \%$ & $32 \%$ & $52 \%$ \\
\hline 3 & Cara/teknik penyajian & $0 \%$ & $0 \%$ & $16 \%$ & $28 \%$ & $56 \%$ \\
\hline 4 & Interaksi dengan peserta & $0 \%$ & $0 \%$ & $8 \%$ & $36 \%$ & $48 \%$ \\
\hline 5 & $\begin{array}{l}\text { Pengelolaan pelatihan (penguasaan event } \\
\text { dan pengelolaan waktu) }\end{array}$ & $0 \%$ & $0 \%$ & $12 \%$ & $32 \%$ & $56 \%$ \\
\hline \multirow[t]{2}{*}{6} & Improvisasi & $0 \%$ & $0 \%$ & $16 \%$ & $64 \%$ & $20 \%$ \\
\hline & Lain-lain & & & & & \\
\hline 1 & Ruang pelatihan & $0 \%$ & $0 \%$ & $4 \%$ & $28 \%$ & $68 \%$ \\
\hline 2 & Sound system & $0 \%$ & $0 \%$ & $0 \%$ & $32 \%$ & $68 \%$ \\
\hline 3 & Kelengkapan lainnya (.....) & $0 \%$ & $0 \%$ & $0 \%$ & $36 \%$ & $64 \%$ \\
\hline
\end{tabular}

Topik-topik pembimbingan yang diberikan pada kegiatan ini tergolong baru bagi peserta. Hal ini karena topik ini merupakan program target dari Kemenparekraf yaitu pengembangan wisata berbasis CHSE, pelayanan prima dan EPP. Sebanyak $100 \%$ peserta puas dengan topik yang dipilihkan dalam kegiatan ini. Kepuasa $100 \%$ tersebut terdiri dari 56\% menyatakan sangat baik (sangat puas), 36\% menyatakan baik (puas), dan $8 \%$ menyatakan cukup. Kepuasan peserta suatu kegiata terhadap pemilihan topik/tema menggambarkan penambahan pengetahuan peserta terkait dengan materi yang disampaikan (Tabel 2). Peserta juga memberikan penilaian yang baik terhadap penguasaan materi oleh semua narasumber. Penjabaran materi yang diberikan bisa diterima oleh peserta dilihat dari antusiasnya dalam pelatihan. Peserta yang menilai baik/bagus penguasaan materi ada sebanyak $56 \%$ dan peserta yang merasakan cukup ada $12 \%$. Metode yang digunakan oleh narasumber dalam penyajian materi bimtek peserta yang merasakan baik sekali/memuaskan ada 52\% karena disajikan dalam bentuk power point dan gambar yang menarik dan diakhiri sesi diskusi antara peserta dan narasumber, sedangkan peserta yang merasakan baik/bagus ada 32\%, dan peserta yang merasa cukup ada $16 \%$. Cara/teknik penyajian yang diberikan narasumber ke peserta, peserta yang merasakan baik sekali/memuaskan ada $56 \%$, sedangkan peserta yang merasakan baik/bagus ada $28 \%$, dan peserta yang merasakan cukup ada $16 \%$. Interaksi yang diberikan oleh narasumber peserta yang merasakan baik sekali/memuaskan ada $48 \%$ karena dilihat keaktifan peserta dalam diskusi, sedangkan peserta yang merasakan baik/bagus ada $36 \%$, dan peserta 
yang merasakan cukup ada $8 \%$. Pengelolaan pelatihan (penguasaan event dan pengelolaan waktu) peserta yang merasakan baik sekali/memuaskan ada $56 \%$ waktu mulai pelatihan dan selesai pelatihan sesuai dengan jadwal susanan acara, sedangkan peserta yang merasakan baik/bagus ada 32\% dan peserta yang merasakan cukup ada $12 \%$. Improvisasi yang diberikan narasumber kepada peserta bimtek hasil kuesioner peserta yang merasakan peserta yang merasakan baik sekali/memuaskan ada $20 \%$, peserta yang merasakan baik/bagus ada $64 \%$ dan peserta yang merasakan cukup ada $16 \%$.

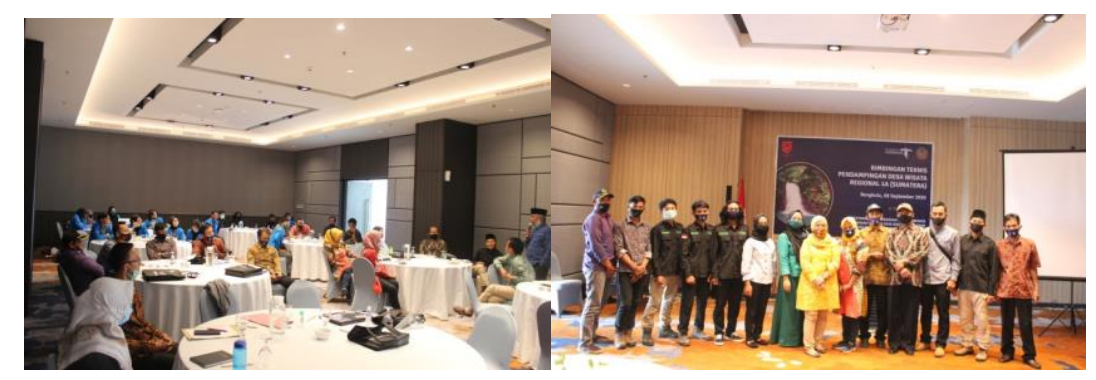

Gambar 5 Suasana diskusi dalam kegiatan pengabdian pada masyarakat

Ketetapan waktu suasana penyelanggaraan pelatihan yang dilaksankan peserta yang merasakan baik sekali/memuaskan ada 52\% diperkirakan karena waktu dimulainya pelaksanaan sesuai dengan jadwal pelatihan, sedangkan peserta yang merasakan baik/bagus ada 44\% dan yang merasakan cukup ada 4\%, Kelengkapan materi yang di sampaikan dalam bimtek peserta yang merasakan baik sekali/memuasakan ada $58 \%$ karena materi yang disajikan begitu lengkap sehingga peserta merasapuas, sedangkan peserta yang merasakan baik/bagus yaitu 34\% dan peserta yang merasa cukup ada $8 \%$. Alat bantu dalam penyelanggaraan pelatihan peserta yang merasakan baik sekali/memuaskan ada 54\% karena peralatan yang disiapkan untuk perlengkapan bimtek lengkap, sedangkan peserta yang merasakan baik/bagus ada $38 \%$ dan peserta yang merasakan cukup ada $8 \%$.

Ruang pelatihan yang disediakan dalam pelatihan bimtek peserta merasakan kenyamanan (Gambar 5) sekali/memuaskan ada $68 \%$ karena ruang pelatihan yang bersih, ber-ac, dan menjaga social distancing, sedangkan peserta yang merasakan baik/bagus ada $28 \%$ dan yang merasakan cukup ada $4 \%$. Sound system yang disediakan dalam pelatihan peserta yang merasakan baik sekali/memuaskan ada $68 \%$ karena sound system keperluannya yang tersedia lengkap dan peserta yang merasakan baik/bagus ada 32\% Kelengkapan lainnya yang disediakan dalam pelatihan peserta merasakan baik sekali/memuaskan ada $64 \%$ dari peserta dan peserta yang merasakan baik/bagus ada $36 \%$.

\section{KESIMPULAN}

Kajian ini menghasilkan kesimpulan bahwa bimbingan teknis pendampingan desa wisata Regional 1A (Sumatera) dilaksanakan secara efektif dengan hasil presentase yang menunjukan hasil baik (cukup, baik, baik sekali). Materi yang diberikan oleh para narasumber mengenai Sadar wisata dan Sapta Pesona; Clean, Health, Safety dan Environmetal Sustainability (CHSE); dan Pelayanan Prima, serta Exploring, Packaging dan Presentation sangat menarik bagi peserta untuk pengembangan desa wisata di daerah peserta. Peserta khususnya perangkat Desa Sumber Urip diharapkan menerapkan setiap pengetahuan CHSE (Clean, Healt, Safety dan Environment), Pelayanan Prima, dan serta Exploring, Packaging dan Presentation sehingga dapat meningkatkan pendapatan desa dan masyarakat, perluasan kesempatan dan lapangan kerja, dan mendorong kegiatan industri penunjang pariwisata dan industri sampingan lainnya.

\section{UCAPAN TERIMA KASIH}

Penulis menyampaikan terima kasih kepada Kementerian Pariwisata dan Ekonomi Kreatif, Universitas Prof. Dr. Hazairin, SH Bengkulu, dan para peserta kegiatan.

\section{DAFTAR PUSTAKA}

Andayani, A. A. I., Martono, E., \& Muhamad, M. (2017). Pemberdayaan masyarakat melalui pengembangan desa wisata dan implikasinya terhadap ketahanan sosial budaya wilayah (Studi di Desa Wisata Penglipuran Bali). Jurnal Ketahanan Nasional, 23 (1), 1-16.

Brunner, E. (2010). New paradigm of tourism: Review of the literature from 2005- to 2009. Scientofoc Research in 
Tourism.

Fitriana, R., Simanjuntak, D., \& Dewanti, R. (2020). Pembekalan materi CHSE (Cleanliness, Health, Safety and Environmental Sustainability) dalam training of trainers akademisi pendamping desa wisata. CARADDE: Jurnal Pengabdian Kepada Masyarakat, 3(1), 138-145.

Gautama, B. P., Yuliawati, A. K., Nurhayati, N. S., Fitiyani, E., \& Pratiwi, I. I., (2020). Pengembangan desa wisata melalui pendekatan pemberdayaan masyarakat. Bernas: Jurnal Pengabdian kepada Masyarakat, 1 (4), 355369.

Hakim, N., Hayati, S., Lumbu, A. A., Rahmawati, N. I., \& Septiyana, L. (2019). Pemberdayaan Kelompok Sadar Wisata (Pokdarwis) Dalam Mengembangkan Ekowisata Desa Gunung Rejo Kecamatan Way Ratai. DEDIKASI: Jurnal Pengabdian Masyarakat, 1 (2), 235-254.

Hermawan, H. (2017). Pengaruh daya tarik wisata, keselamatan dan sarana wisata terhadap kepuasan serta dampaknya terhadap loyalitas wisatawan: studi community based tourism di Gunung Api Purba Nglanggeran. Wahana Informasi Pariwisata: Media Wisata, 15(1), 562-577.

Kementerian Pariwisata dan Ekonomi Kreatif. (2012). Buku Pedoman Pokdarwis. Direktur Jenderal Pengembangan Destinasi Pariwisata, Kementerian Pariwisata dan Ekonomi Kreatif.

Klimchuk, M.R., \& Krasovec, S.A. (2002). Desain Kemasan. Erlangga.

Kotler, P. \& Amstrong, G. (2001). Prinsip-Prinsip Pemasaran. Ed. 1. Erlangga.

Kotler, P., \& Keller, K. L. (2009). Manajemen Pemasaran. Jilid 1. Ed. 13. Erlangga

Peraturan Menteri Kebudayaan dan Pariwisata Nomor PM.04/UM.001/MKP/2008 tentang Sadar Wisata.

Pratama, D. (2019). Gerakan desa sadar wisata : Pengabdian pada masyarakat Desa Penyak Kabupaten Bangka Tengah. Al-Quwwah : Jurnal Pengabdian Masyarakat, 3(1), 49-74.

Kurniawan, A., \& Prakoso, B. S. E. (2008). The influence of spatial urbanization to regional condition in periurban areas of Yogyakarta. Forum Geografi, 22(1), 27-43.

Rahim, F. 2012. Pedoman Kelompok Sadar Wisata. Kementrian Pariwisata dan Ekonomi Kreatif.

Ritchi, H., Zulkarnaen, R., Dewantara, Z., \& Prayogi, Y. (2018). Pemanfaatan teknologi informasi dalam upaya peningkatan aksesibilitas UKM (Desa Wisata) kepada pasar di lokasi wisata pangandaran dan sekitarnya, Jurnal Pengabdian Kepada Masyarakat, 2(1), 36 - 40.

Rusyidi, B., \& Fedryansah, M. (2018). Pengembangan pariwisata berbasis masyarakat. Jurnal Pekerjaan Sosial, 1(3), 155-165.

Yadisaputra, M., \& Palupi, S. (2018). Aware of tourism? Is it important to apply it to the community in Batulayang Tourism Village - Bogor Regency? [Sadar Wisata? Apakah penting penerapannya pada masyarakat di Desa Wisata Batulayang - Kabupaten Bogor]. Proceeding of Community Development, 2(1), 682-691. 